\title{
ANTENUPTIAL TRANSFERS AS FRAUDS ON MARITAL RIGHTS IN PENNSYLVANIA
}

\section{PhILIP A. BREgY $\dagger$ and RoY Wilkinson, JR.}

The recent decision of the Pennsylvania Supreme Court in Kirk $v$. Kirk $^{1}$ is more interesting than a casual reading might indicate. Indeed, to one with merely a general knowledge of the law the decision itself will probably be less startling than the fact that it constitutes a departure from a rule which was commonly believed to have dated from seventeenth century England and which has been followed in this country practically without dissent for well over a century.

A widower, three days before his second marriage and without the knowledge of his intended wife, conveyed real estate to the children of his first marriage. On little more than these findings, the lower court, in a suit subsequent to the widower's death, held that the conveyance was a fraud on the marital right of the second wife and "void as to her". The Supreme Court reversed and ordered a new trial. "The principle applied [by the lower court] was the fact of conveyance by one of the parties to a treaty of marriage without the knowledge of other was evidence of fraud, sufficient, unless rebutted, to avoid the conveyance." 2 The court said that this "is not the law today," and adopted the following principle: "Either spouse may challenge, as fraudulent, a conveyance of real estate or a gift of personal property made during a treaty of marriage, but mere proof of the conveyance or gift, without the knowledge of the other party, does not constitute a prima facie case of fraudulent transfer. In addition, it is necessary for the party alleging it to prove the fraud, or 'actual fraud,' to use an expression common in the decisions." 3

Even taken at its face value, as merely a shift in the burden of proof, the decision would be important. Since few people have a very clear idea of what constitutes fraud in novel and individualized situations, the importance of being required to prove fraud, instead of permitting the defendant to prove the absence of it, is apparent. To mention but a single example, whatever else the plaintiff must now prove beyond the fact of the secret conveyance in order to show "actual

$\dagger$ A. B., I936, Williams College; LL. B., I939, University of Pennsylvania; Member of the Philadelphia Bar.

$\$$ A. B., I936, Pennsylvania State College; IL. B., 1939, University of Pennsylvania; Member of the Centre County Bar.

I. 340 Pa. 203, I6 A. (2d) 47 (I940), (I94I) 89 U. oF PA. L. REv. 524.

2. Kirk v. Kirk, 340 Pa. 203, 205, I6 A. (2d) 47,48 (I940).

3. Id. at $207,208,16 \mathrm{~A}$. (2d) at 50 . 
fraud", probably he must at least establish the element of reliance-that in marrying he relied on the other spouse's ownership of the property in question. In other words, the attorney is placed in the unenviable position of appealing to the conscience of a chancellor and is at the same time required to prove that his client married for money. Add to this the necessity of proving the requisite "fraudulent intent", whatever that might be, and it becomes evident that the shift of the burden of proof will ordinarily make the difference between success and failure.

But in practical effect, the decision means more than this. The rule which was rejected has been variously described as a rule of presumed fraud, constructive fraud, imputed fraud, and even fraud in law. As will appear more fully later, this terminology is not entirely misleading, for once the secret conveyance had been established, the fraud could be "rebutted" only by showing equitable considerations to support the transfer, e. g., that it was a reasonable provision for the children by a former marriage, or to satisfy a moral obligation; proof that there was no representation or reliance was apparently of no avail. In this sense, the rejected doctrine was a rule of substantive law.

To understand the former rule as well as to evaluate the Pennsylvania court's departure from it, it is necessary to examine an interesting line of cases showing the doctrine's modest origin in England and its subsequent development when imported into this country. As indicated in the portion of the Kirk opinion quoted, the discarded doctrine not only seemed to be based on the assumption that one has some sort of legally protected interest in an intended spouse's property before marriage, but also suggested that the law favors this interest to the extent of implying a wrongful invasion of it from the mere fact of a secret conveyance during the engagement. This, however, was not the rule originally announced by the English courts.

Apparently the first reported case on the subject is Howard $v$. Hooker, 4 decided in 1673. There a widow had secretly deeded her interest in her first husband's estate to a trustee for her sole and separate use while she was engaged to her prospective second husband. The evidence showed that previously her fiance, suspecting that she was about to do just this, broke off the engagement "which was afterwards brought on again by some Friends of the [widow] and that the [plaintiff] was induced to marry [her] upon the Hopes and Confidence of having the Interest she had in the Estate of . . . her former husband, without which he would never have married her . . ." In spite of this, the widow nevertheless deeded the property. Upon discovering

4. 2 Chan. Rep. 8I, 2I Eng. Rep. R. 622 (I672-3). See also Lance v. Norman, 2 Chan. Rep. 79, 2I Eng. Rep. R. 62I (I672-3), decided about the same time, but very briefly reported. 
the fact after the marriage, the husband instituted a suit in equity and was successful in having the deed set aside as a fraud on his marital rights. Even from the sparse report, it is plain that this was a case where fraud was actually proved rather than presumed, for the elements of bad faith, misrepresentation, and reliance clearly appear. The woman had used the device of a sole and separate use as a means of secretly barring her intended husband's common-law interest in her propertyan interest which apparently constituted the man's sole reason for marrying her. But before discussing other aspects of this case it is probably advisable, by reviewing a few of the subsequent English decisions, to demonstrate the evolution of the doctrine to its modern form.

Hunt v. Matthews ${ }^{5}$ and King v. Cotton ${ }^{6}$ are examples of the restraint exercised by the early courts in applying the new principle. They also constitute the foundation for the important qualification that an antenuptial conveyance will not be set aside where there are equitable considerations to support it. Thus, in the first case, it was decided that the fact that the transfer was in favor of children of a former marriage was sufficient to negative any idea of fraud. ${ }^{7}$ In King v. Cotton, the conveyance was likewise for the benefit of children by a former marriage and was made by a woman who had declared that if she married again "her second husband would marry her for love." This was, however, an even weaker case for setting aside the deed, for the conveyance was made openly and before her second engagement.

Countess of Strathmore v. Bowes ${ }^{8}$ was another clear case against setting aside the transfer, but, possibly because it was argued so strenuously by the plaintiff, long opinions were delivered and it has become a leading authority. The facts are reminiscent of a Fielding novel or a Sheridan play. The countess, a widow of fabulous wealth but of questionable intelligence, was engaged to one Grey, a nondescript character who soon passed out of the picture. While so engaged, the countess transferred her estate in trust for her sole and separate use. This was done perfectly openly with the full knowledge and consent of Grey and would have caused no difficulty had it not been for the appearance of a man named Bowes-a lieutenant on half pay, "in a regiment of foot,

5. I Vern. 408, 23 Eng. Rep. R. 549 (I686).

6. 2 P. Wms. 674, 24 Eng. Rep. R. 9r2 (1732).

7. This case was later criticized on the ground that, while the general principle was correct, the mere fact of provision for children by a former marriage is not sufficient in itself to negative fraud. See Downs v. Jennings, 32 Beav. 290, 295, 55 Eng. Rep. R. II4, II6 (I863); I Roper, Real Property (I824) I6I; 2 VAIZey, SettleMENTS (I887) I584.

8. 2 Cox 28, 30 Eng. Rep. R. I4, I Ves. jun. 22, 30 Eng. Rep. R. 2 II (1789), aff'd $s u b$ nom. Bowes v. Bowes, 6 Brown 427, 2 Eng. Rep. R. II78 (H. L. I797). See the historical paper on this case by Shannon, The Countess of Strathmore v. Bowes (xo23)

I CAN. B. REv. 425 ; it is interesting to note that that author treats the case merely as a legal curiosity dealing with a principle that has become obsolete. 
and greatly distressed in his circumstances, and possessed of little or no property." Bowes, not a man to sit idly by and observe so rich a prize go to waste on Grey, "recommended himself to the [countess's] notice, and ingratiated himself into her favor by various arts and contrivances, particularly by aspersing her character in the newspapers, and afterwards pretending to vindicate her from such aspersions, by engaging in a pretended duel . . . ." The countess, who was "a woman subject to sudden and violent impulses of generosity," rushed to comfort him and found him "in his lodgings at St. James Street where he spoke in a very low tone of voice, and affected to be languid and in great torture, yet expressing . . . great anxiety to be united to her in marriage before his death, which, he said, was fast approaching, and that he did not expect to live twenty-four hours. . . ." She married him the next day, Bowes "pursuing his imposition so far, as to be carried to church on a litter." Naturally disappointed upon discovering that she had conveyed away her property, Bowes sought to have the deed set aside as a fraud on his marital rights. Of course he did not succeed. As Chancellor Thurlow said, Bowes was scarcely the man "to come into Equity and talk of fraud." On the contrary, he thought that the countess's settlement of the property was the only sane thing she had ever done. ${ }^{9}$ Since the transfer was made during the engagement to Grey and with his assent, there was no possible fraud on Bowes, no matter what rule was adopted. The only wonder is how the plaintiff ever expected to win. The opinions of the chancellors, however, are enlightening.

Justice Buller adhered to the strict rule of Howard v. Hooker. He said: "Fraud, as applied to cases of this nature, is falsely holding out an estate to be unfettered, and that the intended husband will, as such, be entitled to it, when in fact it is disposed of from him: and in most cases the husband appears to have actually made some settlement or provision on the wife, on the faith of this . . . but the cases go no further: and if any such proposition as is contended for can be maintained, that a bare concealment is in itself sufficient, it should be equally fraudulent in law and in equity; and yet clearly it is not so at law : and if such a deed were universally void, it would not signify whether it were made in favor of a child of a former marriage or a stranger; yet the cases of Hunt v. Matthews, and King v. Cotton, have determined if such a settlement be made in favor of such a child it is good against

9. "Marriage in general seems to have been Lady Strathmore's object; she was disposed to marry anybody, but not to part with her fortune. This settlement is to be considered as the effect of a lucid interval, and, if there can be reason in madness, by doing this she discovered a spark of understanding." I Ves. jun. 22, 28, 30 Eng. Rep. R. 2II, 2I4 (I789). 
a second husband, who had no notice of it." 10 But Lord Chancellor Thurlow used language which was later interpreted as adopting a broader rule. "If a woman during the course of a treaty of marriage with her makes without notice to the intended husband a conveyance of any part of her property, I should set it aside, though good prima facie, because affected with that fraud." 11

The requirement of proving actual fraud, with representation and reliance, retained its legal effectiveness, however, at least through I8I3, when Lord Eldon in DeManneville v. Crompton ${ }^{12}$ refused to avoid a voluntary cancellation of promissory notes by a woman on the eve of her marriage. The rule, said the chancellor, "should not be carried to the Extent, that, whenever any thing occurs in general treaty, not entering into Particulars, or showing, that the Marriage actually took place upon such Representations, that Principle is to be applied to a Case, to which it has no Application, and was never intended to be applied." 13

It will be seen, then, that the rule of presumed fraud was not established in the English cases until relatively late in history-a fact slurred over by most of the authorities. ${ }^{14}$

The cases so far reviewed are entirely consistent with the rule adopted by the Pennsylvania court in the Kirk case. The first clear indication that mere proof of a secret transfer during the engagement is sufficient to make out a prima facie case of fraud appears in Roper's textbook on The Law of Property Arising from the Relation Between Husband and Wife, ${ }^{15}$ published in 1824 . The rule in this form was applied in Goddard v. Snoze ${ }^{16}$ and Roper's statement of the principle was subsequently adopted by Vice-Chancellor Wigram in Taylor $v$. $P u g h,{ }^{17}$ where the chancellor expressly repudiated Lord Eldon's opinion and said: "Notwithstanding there are some dicta which may at first be considered as implying the contrary (but which may, I think, be explained), I take the rule of the Court to be correctly stated in Mr. Roper's treatise . . . : 'Deception will be inferred if, after the com-

Io. 2 Cox 28, 29-30, 30 Eng. Rep. R. I4-15 (1789).

II. I Ves. jun. 22, 28, 30 Eng. Rep. R. 2II, 2I4 (I789).

12. I V. \& B. 354, 35 Eng. Rep. R. I38 (1813).

I3. I V. \& B. $354,356,35$ Eng. Rep. R. 138, I39 (1813).

14. The incomplete reports of some earlier cases might make it appear that the rule of presumed fraud was of more ancient origin. But see the reporter's comment in $2 \operatorname{Cox}$ 28, 33, 30 Eng. Rep. R. I4, 16: "Carleton v. Earl of Dorset (2 Vern. 17, 23 Eng. Rep. R. 622 (1686)), which was the most material case in favor of Mr. Bowes (as reported), appeared to be a case in which the wife had assured her second husband that he should enjoy her estate, and therefore was a case of actual fraud . . . Edmonds v. Dennington [unreported, but see brief note in I Eq. Ca. Abr. 59, 21 Eng. Rep. R. 872] is nothing like what it is supposed to be from the mention of it in Vernon."

15. Vol. I at I59 et seq.; compare the statement made by Chancellor Loughborough during the course of the argument in Ball v. Montgomery, 2 Ves. jun. 19I, 194, 30 Eng. Rep. R. 588, 590 (I793).

16. I Russ. 485,38 Eng. Rep. R. 187 (1826).

I7. I Hare 608, 66 Eng. Rep. R. II73 (I842). 
mencement of the treaty of marriage, the wife should attempt to make any disposition of her property without her intended husband's knowledge or concurrence." "18 It was recognized, however, that the defendant may rebut this inference of fraud by showing equitable considerations for upholding the conveyance. Such considerations were found in this case, and the decision is a good example of equity in the grand style. It appeared that the plaintiff here had seduced the woman some time before their marriage, putting her in a position where she could. not refuse him and thus depriving her of her bargaining power in concluding a marriage settlement. For this reason the transfer was upheld.

With Taylor v. Pugh, therefore, the rule of presumed fraud was established. ${ }^{18}$ The transition was important and unfortunate. It became more difficult for this phase of the law to keep pace with the change in the concepts of marriage and the status of woman which began with the romantic movement of the early nineteenth century, in the course of years became part of the general mores of the people, and finally was recognized by the law itself. To anyone familiar with the cases on marriage settlements generally or even the literature and history of the period, it is evident that marriage was in the seventeenth and eighteenth centuries a rather complicated business transaction. The historical background of the cases recognizing that a man's expectant interest in his intended wife's property will be protected in equity is apparent from the opinions and arguments of counsel. Thus, for example, it was argued in Strathmore v. Bowes, "A wife by the marriage contract becomes extinct from the nature of it for several civil purposes; with regard to which she merges in the husband. He becomes liable to all her debts, and answerable for all her acts, that do not amount to felony; and even for that, if committed in his presence; because her mind is supposed to be under his coercion. In order to enable him to answer this he has by the law all her property. It is absurd to say, the wife shall by her own act deprive the husband of what the law has given him. . . . If the wife can by her own act against the consent of the husband make herself independent of him, it will destroy that subordination so necessary in families; which is analogous to that in the state, and tends to support it; for if Lady Strathmore is right in this, the husband is become a cipher in his own house. . . ." 20 Chancellor Thurlow summed up the situation as follows: "The law conveys the marital rights to the husband, because it charges him with all the burthens, which are the consideration, he pays for them; therefore it is a right, upon which fraud may be committed. Out of this

I8. Id. at 6I4, 66 Eng. Rep. R. II73, II76.

19. Followed in Downes v. Jennings, 32 Beav. 290, 55 Eng. Rep. R. Ir4 (1863).

20. I Ves. jun. 22, 22a, 30 Eng. Rep. R. 21 I-212 (I789). 
right arises a rule of law, that the husband shall not be cheated, on account of his consideration." 21

The crux of the situation is that the rule of presumed fraud, stated in Taylor v. Pugh, dispensed with the requirement of proving reliance, and this was the element which would have become increasingly difficult to prove as the years passed by. People may still marry for money, but ordinarily without open admission of the fact; it is no longer regarded as a normal and proper motive. Had the original doctrine of Howard $v$. Hooker been retained, therefore, it would have remained law but would have gradually fallen into disuse.

Be that as it may, the English Courts did not completely lose touch with realities merely because the burden of proving fraud was lightened. In the first place, the English authorities applied the rule only to antenuptial transfers by the intended wife. Similar transfers by the intended husband, even with intent to bar dower, were not subject to this type of attack. ${ }^{22}$ The entire basis for the rule was the extraordinary and present interests a husband had in his wife's real and personal property at common law. ${ }^{23}$ In comparison, the expectancy of inchoate dower, which even after marriage was merely the possibility of an estate, ${ }^{24}$ was a shadow of a shadow. It was not an interest which would ordinarily constitute the inducement on the part of the woman for entering into the marriage contract. A woman might well marry in the hopes of sharing in her husband's wealth, but her legally enforceable rights in this respect were comparatively insignificant. Today, the distinction might well appear as an unfair discrimination against the woman; it was, however, no more than the logical corollary of broader discriminations against women inherent in the common law.

Since the interests of a wife in her husband's property were considered too remote for antenuptial protection, it would seem to follow that when the Married Woman's Property Act reduced the husband's

21. I Ves. jun. 22, 27, 30 Eng. Rep. R. 211, 214 (I789); see also Chancellor Buller's language, quoted pp. 65-66 sipra.

22. See I Roper, REAI Propeisty (2d ed. with Jacob's notes, I84I) 354 n. $u, 32$ Law Library 215 n.; 2 VaIzEy, Seitlements (1887) 1587. In M'Keogh v. M'Keogh, 4 Ir. R. Eq. 338, 346-7 ( 1870 ) it is said: "That doctrine depends on the principle of law that the husband, by the fact of marriage, becomes entitled absolutely to the wife's personalty, and to a certain interest in her real estate, in consideration of which he undertakes a liability for her debts, and incurs other legal obligations for her; and any secret attempt to withdraw any portion of the property of the intended wife during the treaty of marriage from thus passing to the husband is deemed by this Court a fraud on his marital rights. If it were necessary for me to decide this case upon that contention, I should hold that that doctrine does not apply in principle, and has not ever been applied by authority, to the case of a security like this, given by the intended husband on the eve of marriage. The only dealing by an intended husband with his property which was at any time supposed to be a fraud upon the rights of the intended wife was a secret conveyance to bar dower, but even this was held by Lord Hardwicke not to be fraudulent."

23. See, generally, 2 Tiffany, Reat. Property (3d ed. I939) $\$ 484$ et seq.

24. Id. $\S 533$; see also $\$ 487$. 
interest to substantially that of the wife, ${ }^{25}$ the doctrine would no longer apply to a woman's antenuptial transfers. Thus it was suggested by Vaizey, ${ }^{28}$ in discussing the effect of the English Act of 1882 , that: "In the old sense, therefore, of the husband being deprived of something to which as husband he would have had a right if the wife had not before marriage executed a conveyance, fraud on marital right does not appear to be any longer possible. It must, however, be remembered that the change is effected not by abrogation of the doctrine, but by withdrawal of the subject-matter to which it is capable of application." This was the decision of the Scottish Court of Sessions in Lyon v. Lyon's Trustee, ${ }^{27}$ where the court considered the interests remaining in the husband after the Act "too remote" to support an action to set aside a secret deed by the woman during a treaty of marriage. Apparently, therefore, the doctrine of presumed fraud has now been abandoned in England, though relief will still probably be granted in those extraordinary cases where actual fraud can be proved. ${ }^{28}$

An interesting dictum by Justice Brewer, then of the Supreme Court of Kansas, suggested a similar abrogation of the doctrine of antenuptial fraud in this country as a result of statutory modification of marital rights. After pointing out the difficulty of finding fraud in a gift of personal property, he considered the still-remaining reciprocal rights of each spouse in the other's real estate and asked: "But is this inchoate interest, which may never ripen into a complete title, and which is subject to be defeated during marriage by judicial sale and thereafter by the payment of debts, such an interest as will justify a court in pronouncing fraudulent and void the ante-nuptial voluntary conveyance of either husband or wife? But it is not necessary to decide this question, and the court declines to express any opinion thereon." 29

Most American courts have answered Justice Brewer's question in the affirmative and held that even an inchoate marital right is sufficient to support a presumption of fraud from a secret antenuptial conveyance. It was early decided that the doctrine should apply to antenuptial conveyances by the man as well as by the woman, and this seems to have

25. Id. § 552 .

26. 2 Vaizey, Settlements (I887) I586.

27. $3 \mathrm{Ct}$. of Session Cases 653 (Scotland, Igor).

28. Cf. M'Keogh v. M'Keogh, 4 Ir. R. Eq. 338 (1870), cited note 22 supra, where although the rule of presumed fraud was rejected in a case involving a transfer by the intended husband, actual fraud was proved and relief granted.

29. Butler v. Butler, 2I Kan. 52I, 526 ( 1879 ); the actual decision was that the conveyance was made before the marriage contract, constituted a reasonable provision for minor children, and hence was valid no matter what rule was applied. Cf. 2 POMEROY, EQUITY (I9I8) ₹ 920;3 Id. (I9I9) §III3, where it is baldly stated that modern legislation has made the early doctrine of antenuptial fraud obsolete-citing no cases. In Tracy v. Thatcher, I35 Kan. 6I 5 , II P. (2d) 691 (1932) proof of actual fraud was required in a brief opinion which did not discuss the rule of presumed fraud 
been generally accepted..$^{30}$ The most carefully considered opinion to this effect is Chandler $v$. Hollingsworth, ${ }^{31}$ with the rationale that the rule was not appiied to an intended husband's conveyance in England because dower in that country could be barred prior to marriage by various devices, among them a conveyance to use or, after the Statute of Uses, by a jointure under the Statute of Henry VIII; in this country where jointures are unknown, the distinction was said to have no place. There is in this type of reasoning, of course, a logical difficulty. Before marriage, the expectancy of dower was precarious in England because it was not given antenuptial protection; it can scarcely be argued either that it should or should not be so protected in this country because it is or is not precarious here. ${ }^{32}$ The nature of the interest after marriage should control, and this, at common law, was the same in both countries. It would not be entirely unreasonable, however, to hold, contrary to the English law, that inchoate dower is a sufficiently substantial interest to cause a woman ordinarily to rely on it as an inducement for marriage, and hence the rule of presumed fraud should apply. This would seem to be the best justification for the American decisions, although the rule so applied constitutes a radical extension of the original doctrine of Howard v. Hooker. A rule designed to protect a husband's extraordinary common-law interests from actually fraudulent antenuptial transfers had developed through a series of minor transitions to a point where it protected a contingent marital right from any secret conveyance during a treaty of marriage. ${ }^{33}$

The American courts, in their enthusiasm for the rule, applied it to protect any interest, no matter how tenuous, one spouse might have in the other's property as a result of marriage. Thus, even where dower had been abolished by statute, an antenuptial conveyance was set aside as a fraud on the wife's homestead rights. ${ }^{34}$ The courts which gave the matter any thought seemed to admit that the doctrine would not apply where the marital interest was no more than that of an expectant heir, as in the case of a husband's gift of personal property, ${ }^{\mathbf{3 5}}$ but anything more than this was in general afforded antenuptial protection.

In Pennsylvania, however, the law on the subject was not settled. The first case came before the Supreme Court in 1859 . At that time,

30. Kelly v. McGrath, 70 Ala. 75 (I88I); Cranson v. Cranson, 4 Mich. 230 (1856) ; Swaine v. Perine, 5 Johns. Ch. 482 (N. Y. I82r) ; see Arnegaard v. Arnegaard, 7 N. D. 475,75 N. W. 797 (I898); cases collected in 2 TIFFany, ReaL PropERTY (3d ed. I939) \$ 506 .

31. 3 Del. Ch. 99 (1867).

32. Cf. (I935) 35 CoL. L. REv. I13, I14-5.

33. With the exceptions noted in the case of a transfer supported by equitable considerations.

34. Arnegaard v. Arnegaard, 7 N. D. 475, 75 N. W. 797 (1898).

35. See I3 R. C. L. \$ ro4. But see the recent decision of LeStrange v. LeStrange, 242 App. Div. 74, 273 N. Y. Supp. 2I (N. Y. 2d Dep't I934), (I935) 35 CoL. L. REv. II3, (I935) 20 CoRN. L. Q. 38I. This case, however, probably involved actual fraud. 
the marital rights of the husband were limited by the Act of $1848,{ }^{36}$ which provided that all property "whether consisting of real, personal or mixed, which may be owned by or belong to any single woman, shall continue to be the property of such woman, as fully after her marriage as before ...." This act was construed to put a married woman's property beyond the reach of the husband or his creditors, but not to add anything to the wife's powers over it. Hence she could not dispose of her property without her husband's consent after the act any more than before. ${ }^{37}$ Under the Act of $1855,^{38}$ a husband could take his intestate interest in real and personal property against the wife's will. ${ }^{39}$ Thus, although the husband's present interests at common law were wiped out, he retained a contingent interest in a portion of her property which would ripen on her death if he survived her. This was the background of Belt $v$. Ferguson, ${ }^{40}$ where the lower court had set aside a deed for separate use made by a woman before marriage without her intended husband's consent. In a rather casual per curiam opinion of fourteen lines, the Supreme Court affirmed. Apparently the effect of the Act of 1848 was argued but the opinion simply stated that there was "nothing in that act to affect the rule."

This case was followed by Duncan's Appeal ${ }^{41}$ and Robinson $v$. $B u c k,{ }^{42}$ where the rule of presumed fraud was applied to set aside transfers of both real and personal property by women immediately before their marriages. Neither opinion discusses the merits of the principle which, it was said, had "stood the test of experience too long to be open to dispute now." Since at the dates of those decisions a husband would have at the death of the wife an interest in her property, both real and personal, which she could not have disposed of during coverture without his consent, these holdings are justifiable, at least under the American extension of the rule. They were decided, however, in ill-considered opinions which gave no attention to the exact nature of the interest being protected. Thus the stage was set for the confusion that followed.

In Ross's Appeal, ${ }^{43}$ the wife attacked the validity of sealed notes executed by the husband the day he married her. This was apparently the first Pennsylvania case dealing with a transfer by an intended hus-

36. Pa. Stat. Ann. (Purdon, I930) tit. 48, $\$ 64$.

37. See Haffey v. Carey, $73 \mathrm{~Pa}$. 43I (1873); Moore v. Cornell, $68 \mathrm{~Pa} .320,323$ (I87I); Haines v. Ellis, 24 Pa. 253, 255 (I855); Keen v. City, 8 Phila. 49 (Pa. I871); Husbands, Law of Married Women in Pennsylvanta (I878) \$64.

38. P. L. 430 (I855).

39. See HuSBands, MarRied WOMEN (1878) \& I53.

40. 3 Grant 289 (Pa. I859); cf. In re Guardians of Elliot, 2 Clarke I, 5 (Pa. L. J. Rep. I843).

41. $43 \mathrm{~Pa}$. 67 (1862).

42. 7I Pa. 386 (1872).

43. I27 Pa. 4 , I7 Atl. 682 (I889). 
band and since it concerned a transfer of personal property, over which he would still have absolute dominion after marriage, it was clearly a case where the rules relating to antenuptial fraud could have no application. The notes were upheld, however, only because they were said to constitute a reasonable provision for children of a former marriage.

Potter v. Fidelity Co. ${ }^{44}$ decided in I9or, also involved a man's antenuptial transfer of personal property. The Supreme Court adopted the opinion of Judge Willson in the lower court which refused relief to the wife who sued during the husband's lifetime. The precise ground for this decision is not clear. Although the rule of Duncan's Appeal ${ }^{45}$ was recognized as retaining legal significance in regard to transfers by an intended wife (a doubtful point in itself, as will be subsequently indicated), it was doubted whether a similar doctrine could be applied to a husband's gifts in view of his absolute control over his personalty even after marriage. This, of course, was correct and should have decided the case. Instead, the bill was held bad merely because it had been brought during the lifetime of the husband, and, ignoring everything that had been said previously in the opinion, the judge suggested that if the husband predeceased her, the wife would "undoubtedly" have the right to set aside the gift.

Windolph v. Girard Trust Co. ${ }^{46}$ concerned a trust deed of personal property made by a married woman during coverture. It is a leading case to the effect that pursuant to the Act of $1893,{ }^{47}$ a married woman during coverture may dispose of her personal property as freely as her husband may dispose of his. For some reason, however, the court was concerned about the setting aside of the woman's antenuptial transfer of personalty in Duncan's Appeal, discussed above. That case should have given no difficulty in this respect for it was decided under the Act of 1848 , which, as has been stated, did not increase a married woman's dominion over her property. Instead of merely indicating that fact, the court revived Duncan's Appeal, distinguishing it on the ground that there an antenuptial transfer was involved and not, as here, a transfer during coverture. No explanation was given for the rather curious suggestion that a wife has less dominion over her property before marriage than afterward. ${ }^{48}$

44. No. 2, I99 Pa. 366, 49 Atl. 86 (I90r) ; cf. Coleman's Estate, 193 Pa. 605, 44 Atl. 1085 (1899) (where the deed was made prior to the engagement); Barnhart v. Grantham, I97 Pa. 502, 47 Atl. 866 (I90I) (a case of actual fraud).

45. 42 Pa. 67 (I862), cited p. 7I supra.

46. 245 Pa. 349, 9I Atl. 634 (I9I4). P. L. 332 .

47. PA. STAT. ANN. (Purdon, I930) tit. 48, §3I et seq.; supplanting Act of 1887 ,

48. $245 \mathrm{~Pa} .349$ at 367 , 91 Atl. 634 at 639 (1914). It might be argued that the distinction can be justified on the tacit assumption of the common law that a woman has no mind of her own but is always being coerced by somebody. Thus, the position might be taken that a man has a right to have the property of his intended wife pro- 
In Weaver $v$. Welsh, ${ }^{49}$ a Superior Court case decided in I9I9, a man, the day before he married, had secretly conveyed away some real estate to his sister. Ejectment was brought by the grantee of the sister against the wife, while the husband was still living. Following Potter v. Fidelity Co., the court held that the wife's defense of fraud was not available to her until after the husband's death. But the opinion did not stop there; it went on to quote the long dictum in the Potter case which threw doubt on the wife's right to relief in any event because of the husband's absolute dominion over his property. It is plain, however, that such reasoning could not be applied to a conveyance of real estate, because, unlike personalty, real property may not be alienated by a married man free of his wife's dower even under modern statutes. ${ }^{50}$

The confusion with regard to antenuptial transfers of personalty was finally clarified by the holding of Fritz's Estate, ${ }^{51}$ where a husband's sealed note, executed three days before his marriage, was upheld as against the claim of the wife. The Superior Court merely relied on the cases dealing with a husband's absolute dominion over his personal property during marriage. Although the problems created by the older cases were ignored rather than solved, the decision is clearly correct. The only interest either spouse has in the other's personal property today is merely the hope of an expectant heir. Certainly fraud should not be presumed from a gift the day before the wedding when it could not have been attacked if made the day after.

When Kirk v. Kirk came before the Supreme Court, therefore, the Pennsylvania law was in flux. From the above review of the cases, it will be seen that the only actual holdings in support of the rule of presumed fraud were Belt v. Ferguson, Duncan's Appeal, and Robinson v. Buck, all cases concerning transfers by the intended wife and decided prior to the Married Woman's Property Act of $1893 .{ }^{52}$ There were no appellate decisions actually applying the rule to transfers by the intended husband ${ }^{53}$ or to a woman's transfers after 1893 . The dicta in support of so extending the rule were numerous but conflicting and unreliable. The suggestions that the rule should be applied to all antenuptial transfers, even of personalty, over which each spouse now has absolute dominion after marriage, were plainly wrong and contrary to the holding of the Superior Court in Fritz's Estate. Yet there was no indication that a different rule should be applied to conveyances of real

tected from the coercion of her father or brother until he marries her and is in a position to coerce her himself.

49. 7 I Pa. Super. I84 (IgIg)

50. Bridgeford v. Groh, 306 Pa. 566, I60 Atl. 451 (I932).

5I. I35 Pa. Super. 463, 5 A. (2d) 601 (1939).

52. P. L. 344 (1893).

53. Baird v. Sterne, I5 Phila. 339 (C. P. Pa. I882) applied the rule to set aside a husband's conveyance, but the case was not appealed. 
estate. The suggestions in Potter v. Fidelity Co. and Weaver v. Welsh that the rule applicable to a woman's transfer should not be applied to transfers by the man might have had some validity at common law. But at the time the suggestions were made, when the respective marital property rights of each spouse were substantially equal, this was not true. $^{54}$

The state of the decisions indicated the necessity for a re-examination of the current application of the rule. For the reasons already discussed, the suggestions that fraud could be presumed from a secret antenuptial gift of personalty were easily rejected and Fritz's Estate followed. There remained, however, the problem of conveyances of real estate, where the situation was somewhat different: even under the Act of 1893 , a married woman is still unable to convey her real estate without her husband's consent, and, conversely, a married man is still unable to convey his land free of the statutory equivalent of dower unless his wife joins. With the additional power of each spouse to take against the other's will, it is evident that each spouse has an interest in the other's real property analogous to inchoate dower at common law, an interest which lies between a contingent estate and a bare expectancy. It might well be argued that this interest should be protected by the rule of presumed fraud under the American interpretation of the doctrine. The Supreme Court in the Kirk case, however, going back to the original rationale of the rule in England, stated that the hope of sharing in the other spouse's real estate was not "such a present and certain interest as . . . would ordinarily constitute the consideration for marital obligations." 55 The opinion did not preclude the possibility of proving that the marital interest in the other's real property did constitute the inducement for marriage in a particular case; it merely rejected the tacit assumption that all marriages are consummated with this purpose in mind. Reliance is no longer presumed; it must be proved.

Implicit in the Kirk decision is a clarification of the nature of the fraud which gives rise to the power to set aside an antenuptial transfer, for the presumption applied in the prior cases had tended to obscure the basis of the equitable right. It will be noted in this respect that there is no uniform meaning to the term fraud. On the one hand the term is used to describe unconscionable dealings which induce a disadvantageous change of position on the part of another and give rise to an

54. In view of this state of the law, it is perhaps excusable that the following rather puzzling statement was recently made in what is otherwise a very enlightening treatise: "Although much shaken recently, the rule seems to be that a transfer or lien by a spouse, either in contemplation of or after marriage, with the intent to deprive the other spouse of his or her maritaly property rights is fradulent." (Footnotes omitted.) Bushong, Pennsylvania Jand Law (I938) \$670.

55. $340 \mathrm{~Pa}$. 203, 207, I6 A. (2d) 47, 50 (I940), with which compare Justice Brewer's dicta, note 26 supra. 
action for deceit ${ }^{56}$ or a proceeding to set aside a contract so induced; ${ }^{57}$ here misrepresentation and reliance are important. On the other hand, the term fraud is used to describe a voluntary transfer by an insolvent debtor. $^{58}$ In this latter situation the entire theory of the wrong is radically different; the law seems to recognize that one has certain rights in his debtor's property with which there can be wrongful interference regardless of intent, misrepresentation or reliance. The remedy in the insolvency cases, moreover, is obviously not to set aside the contract of indebtedness nor to bring an action for damages, but to set aside the transfer itself. A conveyance during coverture "in fraud of dower" is analogous to a transfer in fraud of creditors in that the interest of the wife is attached to the land and cannot be defeated regardless of the good faith of the parties. An antenuptial transfer, however, has never been so regarded. No matter how far the presumption of fraud is carried, it is nevertheless fraud in the first sense described-in the sense of unconscionable dealings inducing an injurious change of position. This is evident if only from the fact that the secrecy of the transaction is in all cases a necessary element; if the intended spouse is informed of the transaction, he obviously cannot complain. But the peculiarity of this type of wrong is that while the fraud is of the kind that in other situations gives rise to an action for deceit or a proceeding to set aside the contract, the remedy here is to set aside the transfer. The reason for this is plain. Since the injury complained of is the depletion of the other spouse's estate, an action for deceit against the estate would scarcely be profitable. The annulment of the marriage would likewise be inapproprate even if annulments or divorces could be granted on this ground, which, of course, they cannot.59 That equity has chosen the only particular remedy available, and that this remedy happens to be similar to that granted in insolvency proceedings, should not cause confusion. The fraud complained of is still fraud in the first sense. The danger of drawing false analogies, however, is apparent where the very elements of this type of fraud, misrepresentation and reliance, are presumed rather than proved. This particular aspect of the problem was not discussed in the Kirk opinion but an awareness of the problem is suggested by a cryptic footnote referring to Harlan v. Maclaughlin, ${ }^{80}$ a case holding that proof of actual fraud is necessary to set aside a transfer by a debtor prejudicial to future creditors; the suggested analogy is interesting and rather instructive. The important thing, however, is that the decision, in requiring proof of fraud, makes clear that

56. Emery v. Third Nat. Bank of Pittsburgh, 314 Pa. 544, I7r At1. 88I (1934).

57. New York Life Insurance Co. v. Brandwene, 316 Pa. 218, I72 Atl. 669 (I934).

58. See Pa. Stat. ANN. (Purdon, I930) tit. 39, \$ 354 et seq.

59. See Hannah Allen's Appeal, 99 Pa. I 96,200 (1882).

60. $90 \mathrm{~Pa} .293$ (I879). 
the basis of the suit is fraud in its pure sense rather than a wrongful interference with some sort of a property right.

The nature of the burden now on the plaintiff of proving actual fraud remains an open question. In the case of an antenuptial transfer of personal property, clearly the burden would be as heavy as that of proving fraud in such a transfer during marriage, where it is well established that even an intent to bar the other spouse's intestate rights is insufficient to establish fraud. Anything more than a mere colorable transfer, therefore, can no longer be avoided. ${ }^{61}$

In the case of an antenuptial conveyance of real estate the burden will be somewhat lighter. Unlike the hope of succeeding to the other spouse's personal estate, the interest of one spouse in the other's real estate, while remote and contingent, is something more than the mere hope of an expectant heir. The extent of the proof now necessary to show fraud, however, did not arise in the Kirk appeal, and the opinion expressly left this question open. "For example, can it be shown that Mr. Kirk made any representation to plaintiff of his existing property, what the representation was, and whether it was relied on? Did he, in making the conveyance, intend to satisfy an existing obligation to his grantees . . . in circumstances in which the effect on his intended wife's future rights in this property would, in a legal sense, be only incidental? . . . Or, did he make the conveyance, not to satisfy a bona fide obligation, but with the intention of depriving her of rights which, expressly or by implication, he induced her to believe she would receive by marrying him? We are not attempting to limit or define the scope of the inquiry but merely to illustrate its general nature." 82 Proof of plaintiff's reliance and the transferor's intent will ordinarily be difficult; ${ }^{63}$ but while the Kirk decision abolishes the legal presumptions, it does not interfere with the power of a chancellor to draw reasonable inferences from all the evidence in the case.

Proof of actual fraud, therefore, will not be impossible, although recovery will be limited to rather unusual situations. With the abolition of the special presumptions favoring this type of suit, the cycle is now completed. The rule which was first suggested by isolated statements of the English chancellors, which was adopted by textwriters, then found its way into the decisions, and was extended far beyond its original scope by the American courts, has now been discarded. Once more, equity will grant relief only on facts analogous to those in the original case of Howard v. Hooker.

6r. See review of the Pennsylvania cases in Note (1939) 5 U. of Pitr. L. REv. 78.

62. 340 Pa. 203, 208, I6 A. (2d) 47, 50 (I940).

63. The dead man rule will add to this difficulty where the suit is brought after the other spouse's death. 